\title{
Balutan Identitas Maskulin pada Pengguna Tato dari Perspektif Fenomenologi Levinas
}

\author{
Arni Ernawati ${ }^{1}$, Rustono Farady Marta ${ }^{2}$ \\ ${ }^{1}$ Diploma of Broadcast Journalism, Fakultas Ilmu Komputer, Universitas Dian Nuswantoro, Jln. Imam Bon- \\ jol No.207, Pendrikan Kidul, Kota Semarang, 50131, Jawa Tengah, Indonesia \\ ${ }^{2}$ Program Studi Magister Ilmu Komunikasi, Program Pascasarjana, Universitas Bunda Mulia, Jln. Lodan \\ Raya No.2, Jakarta Utara, 14430, DKI Jakarta, Indonesia \\ 'ernawatiarni@gmail.com
}

Maskulinitas merupakan identitas yang berharga terkhusus bagi seorang laki-laki, tak heran banyak dari laki-laki mencoba berbagai cara untuk mengekspresikan maskulinitas mereka. Tato dianggap sebagai salah satu simbol maskulinitas bagi laki-laki. Tato dapat menjadi representasi identitas dan ekspresi seseorang, banyak dari laki-laki mengekspresikan diri mereka dengan simbol-simbol tato yang dilukis ditubuh mereka. Tato dalam pandangan masyarakat memiliki makna yang beragam, dalam beberapa komunitas masyarakat adat di Indonesia tato bahkan menjadi budaya yang sarat dengan pesan hidup sementara di masyarakat modern tato selain penyampai pesan juga sebagai unsur yang memiliki nilai estetika tersendiri. Simbol maskulinitas berupa tato dianggap memiliki nilai seni yang tinggi dan nilai pesan yang sangat baik untuk mengekpresikan pesan maskulin seseorang.

Kata kunci: identitas, maskulinitas, tato, fenomenologi levinas

\section{Wrapping a Masculine Identity in Tattoos Users from the Perspective of Levinas Phenomenology}

Masculinism is a valuable identity especially for a man, no wonder many men try different ways to express their masculinity. Tattoos considered as one of the symbols of masculinity for men. Tattoos can be a representation of a person's identity and expression, many of the men express themselves with the symbols of the tattoos painted on their bodies. Tattoos in the view of the community has a variety of meanings, in some custom communities in Indonesia the tattoo community has even become a culture full of message of life while in modern society tattoos besides the messanger as well as an element that has its own aesthetic value. Masculinity symbol in the form of a tattoo is considered to have high artistic value and excellent message value to express one's masculine message.

Keywords : identity, masculinism, tattoo, levinas fenomenology

Proses Review : 18 - 31 Agustus 2020, Dinyatakan Lolos: 7 September 2020 


\section{PENDAHULUAN}

Tubuh bagi sebagian orang, menjadi media tepat untuk berekspresi dan bereksperimen (Umar, 2018), khususnya di Eropa, tato biasanya dianggap sebagai bentuk ekspresi dan kreativitas seseorang. Selain menunjukkan individualitas, secara bersamaan tato juga menunjukan bahwa pemiliknya adalah anggota sebuah kelompok komunitas yang menyukai seni melukis tubuh.tak heran jika kemudian timbul aktivitas menghias tubuh menggunakan tato, piercing dan body painting. Tubuh dibentuk dan dikontrol dalam kehidupan sosial dan benarbenar menjadi wadah berbagai tujuan sosial. Setiap bagian tubuh memiliki biografinya sendiri (sejarah hidup). Tubuh meliputi beberapa episode perubahan dan langkah-langkah yang diambil untuk mengatur, mengorganisasikan dan bahkan mengotrol perkembangan tubuh (Rediasa, Sutrisno, 2015). Selanjutnya tubuh yang telah menjadi tubuh sosial ini dijadikan sebagai media atau simbol dan dalam karya ini dibuat sebagai simbol yang membahasakan, bahasa-bahasa non verbal yang tampak dari perilaku tubuh sosial tersebut. Gerak atau pose tubuh manusia yang sering terlihat dalam keseharian merupakan pose gerak tubuh alamiah.

Kebebasan memaknakan ekspresi gerak tubuh manusia sebagai tubuh simbol merupakan bahasa isyarat yang dapat menjadi metafor dalam karya rupa (Rasul, 2018) . Pada tahun 70 (tujuh puluh) sampai 80-an (delapan puluhan), saat mendengar kata tato yang terlintas dalam pikiran adalah gambaran seseorang yang garang, seram, dan identik dengan preman, namun saat ini tato sudah menjadi gaya hidup bagi sebagian orang terlebih di kota besar di Indonesia. Tato merupakan Bahasa Indonesia dari kata tattoo yang berarti goresan, gambar, atau lambang yang membentuk sebuah desain pada kulit tubuh. Konon kata " tato" berasal dari bahasa Tahiti, yaitu "tattau" yang berarti menandai, dalam arti bahwa tubuh di gambar dengan menggunakan alat yang runcing untuk memasukkan zat pewarna di bawah permukaan kulit (Umar, 2018).

Tato adalah gambar atau simbol pada kulit tubuh yang diukir dengan menggunakan alat sejenis jarum (Umar, 2018). Biasanya, gambar dan simbol itu dihias dengan pigmen berwarna-warni. Dulu orang-orang masih menggunakan teknik manual dan dari bahan-bahan tradisional untuk membuat tato. Orang Eskimo, misalnya, memakai jarum dari tulang binatang (Umar, 2018.). Sekarang, orang-orang sudah memakai jarum dari besi, yang kadangkadang digerakkan dengan mesin untuk mengukir sebuah tato. Fenomena tato bukan dilahirkan dari sebuah tabung dunia yang modern dan perkotaan. Secara historis, tato lahir dan berasal dari budaya pedalaman, tradisional, bahkan dapat dikatakan kuno (Umar, 2018).

Keberadaan tato pada masyarakat modern mengalami perubahan makna, tato berkembang menjadi budaya popular oleh anak muda dan mereka menganggap tato merupakan simbol kebebasan dan keragaman. Belakangan ini tato menjadi trend, dan berkembang menjadi bagian kebudayaan pop yang semakin banyak diminati oleh manusia modern. Maka tak heran saat ini banyak kita lihat selebritis Indonesia menjadikan tato sebagai identitas yang melekat pada diri mereka. Kecenderungan tato sampai saat ini sepertinya masih di pegang pada laki-laki yang dirasa cocok untuk memiliki tato. Kesan maskulinitas seharusnya menjadi acuan untuk menempatkan tato sebagai milik pria. Kenyataannya sekarang ini tato bukan hanya di dominasi oleh kaum pria, wanita pun berhak menentukan pilihannya dalam menghias tubuhnya dengan beragam gambar tato. Bisa saja ada faktor lain yang mempengaruhi pemilihan simbol tato oleh kaum wanita sehingga mereka juga ingin menggunakan tato.(Umar, 2018)

\section{METODE PENELITIAN}

Penelitian ini menggunakan penelitian kualitatif deskriptif. Penelitian kualitatif merupakan suatu penelitian yang dicirikan oleh tujuan penelitian yang ingin memahami gejala-gejala yang tidak memerlukan kuantifikasi atau gejala-gejala yang tidak memungkinkan untuk diukur secara tepat atau kuantitatif (Putra, 2015). Penelitian ini menggunakan paradigma interpretatif yaitu melakukan pemaknaan atas pengalaman sehari-hari individu dengan perilaku sosialnya. Penelitian ini termasuk dalam naturalistic inquiry atau penelitian ilmiah yang memerlukan manusia sebagai instrumennya, karena muatan tersebut sarat dalam lingkup yang hendak diamati. Fenomenologi merupakan ilmu yang berasal dari kesadaran, atau cara untuk memahami objek dan peristiwa yang pernah dialami secara sadar (Putra, 2015).

Salah satu teori fenomenologi yang terkenal adalah teori yang dicetuskan Levinas, Levinas adalah seorang fenomenolog. Ia sendiri pernah belajar pada Husserl, bapak fenomenologi, dan Heidegger, murid Husserl. Muncul suatu pertanyaan bagi kita apakah filsafat Levinas boleh disamakan begitu saja dengan fenomenologi? S. Strasser, profesor Belanda asal Austria yang mengenal baik sekali baik fenomenologi Husserl maupun pemikiran Levinas, sampai pada suatu kesimpulan bahwa Levinas tidak termasuk fenomenologi dalam arti kata yang tradisional. Fenomenologi Levinas adalah suatu fenomenologi gaya baru (Sobon, 60). Metode fenomenologi Levinas tentunya tidak jauh berbeda dengan fenomenologi Husserl dan Heidegger yakni tentang intensionalitas. Levinas juga memahami intensionalitas sebagai kesadaran yang selalu terarah pada sesuatu. Tentang intensionalitas, Levinas mengatakan, "Setiap kesadaran adalah kesadaran akan sesuatu, kesadaran itu tidak terlukis tanpa referensi kepada objek yang 'menuntut'nya. Tujuan intensionalitas adalah bukan pengetahuan, tapi ada dalam perasaan-perasaan atau aspirasi, dalam sesuatu yang dinamis pada dirinya sendiri, yang berkualitas 'secara afeksi' atau 'secara aktif'. 
Levinas tidak mengajukan suatu teori. Ia mengajak kita untuk melihat apa yang terjadi apabila kita bertemu dengan orang lain. Ia menunjukkan bahwa data paling dasar dari wawasan manusia bukan cakrawala pengada, melainkan munculnya orang lain di depan kita. Levinas menunjukkan secara fenomenologis bahwa berhadapan dengan sesama kita langsung menyadari diri dipanggil untuk bertanggung jawab atas keselamatannya. Levinas mau mengatakan bahwa begitu seseorang menghadap saya,dan sebelum saya mengambil sikap terhadapnya, saya sudah dibebani tanggung jawab atasnya. Di sini Levinas tidak bicara secara normative. Ia tidak mengatakan bahwa kita harus bertanggung jawab, harus menghormati atau harus memperhatikan orang lain karena ia bicara secara fenomenologis. Ia menunjuk sebuah realitas dalam kesadaran kita. Ia mau membuka suatu lapisan kenyataan dalam kesadaran kita yang umumnya tidak diperhatikan (Sobon, 2018)

Terdapat 3 poin mendasar dalam kaitan studi akan pemikiran Levinas, antara lain, Pertama, Etika sebagai keberadaan yang paling mendasarberkaitan dengan perilaku yang menjadikan manusia lebih beradab. Baik memperlakukan sesamanya, karena keinginan diperlakukan untuk semata-mata mempertahankan hidupnya. Kedua, Sensibilitas subyektif yang memberi tendensi pada hal yang dirasakan manusia, sehingga muncul penerimaan dari dunia akan keberadaannya. Kondisi ini berujung pada transisi yang terjadi mulai dari singgungan terhadap norma di masyarakat, kemudian beranjak pada upaya membiasakan diri dan memberi ketenangan pada lubuk hati. Ketiga, Instruksi akan niatan baik, dimana tubuh tidak berada pada tataran etika dan rasa saja. Lebih jauh daripada itu, terdapat kebaikan yang didasarkan pada esensi transsendental. Berupa pemahaman akan situasi yang tidak sekedar harfiah, bukan pada tataran pemahaman esensial cara manusia menjalankan kehidupan melainkan memberi pemaknaan pada hidup itu sendiri

Levinas mendeskripsikan konsep ketubuhan yang acapkali tidak mampu dihadapkan pada situasi yang berada di luar ekspetasi tubuh itu sendiri (seperti perasaan lemah, kesepian yang melanda, kerinduan pada pendahulu, dst) (Altez \& Albela, 2011). Pada Penelitian ini akan melibatkan beberapa para pegiat seni tato. Berawal dari ketertarikan melihat beberapa teman yang bertato, kemudian dari situ timbul keingintahuan lebih detail mengenai seperti apa dan bagaimana tato itu. Maka dari itu peneliti malakukan sesi wawancara dengan 6 (enam) orang seniman tato. Mereka aktif diberbagai komunitas tato atau seni rupa lain di Kota Semarang khususnya, seperti : Komunitas Workshop Lukis dan Instalasi (WOLU), Komunitas Rumah Pensil, Komunitas Toekang Tattoo, Indonesia Subculture, dan Komunitas Mural Rupa Serba Bisa,. Mereka juga aktif menyuarakan tentang makna tato yang sebenarnya, yang selama ini telah dianggap hal negatif. Keenam narasumber tersebut adalah Helmi Arif Fatoni atau Toni, Irawan atau akrab dipanggil Tukul, Sutong, R. Kokoh Nugroho atau
Kokoh, Alle Susanto atau Ale, dan Sony Hidayat

Toni merupakan seorang pegiat tato yang berasal dari Ungaran, dan merupakan pegiat tato di komunitas Toekang Tatto, Tukul merupakan seorang yang aktif di ISC(Indonesian Subculture) bersama dengan Sutong. Tukul merupakan buruh gambar di Twocooltats Studio dan beralamat Banyumanik Semarang sementara Sutong memiliki studio bernama Urban Tattoo yang berada dirumahnya di Kota Salatiga, sementara Kokoh merupakan pegiat di komunitas Kelas Wolu (Workshop Lukis dan Instalasi) dan Komunitas Rumah Pensil. Sementara dua narasumber lain merupakan orang yang memiliki profesi berbeda dari empat narasumber sebelumnya, Sony merupakan pemilik warung Mie Ayam yang berasal dari Sekaran Gunungpati, Kota Semarang dan merupakan Koordinator Lapangan Panser Biru (Suporter PSIS Semarang). Sedangkan, Ale merupakan Wiraswasta yang juga berasal dari Sekaran Gunungpati Kota Semarang dan merupakan anggota komunitas motor bernama Brokennoken MC

\section{ANALISIS DAN INTEPRETASI DATA}

Etnisitas merupakan wacana yang digunakan untuk membahas ikatan-ikatan kolektif yang didasarkan atas atributatribut kultural, agama, ras, dan kesamaan sejarah. Sebagaimana didefinisikan oleh Eriksen, etnisitas merujuk pada hubungan antar kelompok-kelompok yang anggotanya mendefinisikan diri mereka berbeda dengan kelompok lain. Definisi tersebut menggarisbawahi pembahasan etnisitas yang selalu dikaitkan dengan klasifikasi individu berdasarkan kelompok, dan hubungan antar kelompok-kelompok sosial. Oleh karenanya, melalui konsepsi tentang etnisitas, batas-batas, simbol, dan atribut kolektif dibangun. Dalam konteks ini, etnisitas merupakan 'penanda' bagi keanggotaan kolektif, yang secara sistematis membedakan antara 'kami' dan 'mereka', antara 'insider' dan 'outsider'. Dan, sebagaimana realitas sosial lainnya, simbol, batas-batas, dan atribut etnisitas sebagai identitas etnik merupakan hasil konstruksi yang dinamis dan berlangsung sepanjang waktu. Hal ini dikuatkan oleh pernyataan Barth (1969) yang menekankan bahwa batas-batas etnis memiliki dua ciri: pertama, bahwa batas-batas tersebut secara terus-menerus dibentuk. Proses tersebut merupakan sosial proses yang dapat berupa eksklusi maupun inkorporasi melalui mana kategori kolektif dipertahankan dan direproduksi. Kedua, melalui batas-batas yang menandai keanggotaan kelompok 'kami' dan 'mereka' tersebut, relasi sosial antar kelompok dipelihara.

Inter-relasi antara etnisitas dan eksklusi sosial merupakan konsekuensi dari konsepsi etnisitas yang asosiatif dengan pembahasan mengenai 'kami' dan 'mereka' dimana demarkasi atau batas-batas kelompok dibangun. Melalui atribut dan simbol yang menjadi identitas dan 'penanda' bagi kelompok, maka proses mengeksklusi dan mensubordinasi 'mereka' yang bukan anggota 'kami' berlangsung, 
sebagaimana dinyatakan oleh Yuval-Davis (Setyawati, 2010). Dengan perkembangan teknologi, apa pun dapat terjadi termasuk "memodifikasi tubuh", sesuai dengan keinginan sendiri. Setiap orang mempunyai hak dan kebebasan untuk mengekspresikan atau menunjukkan identitas diri dengan menampilkan sesuatu yang bermakna bagi kehidupannya. (Dalensang, 2019)

Identitas sendiri merupakan bentuk karakter yang melekat dan penanada bagi keberadaan individu, salah satunya maskulinitas yang erat dengan laki-laki. Kamla Bashin (2004) secara sederhana mendefinisikan maskulinitas sebagai definisi sosial yang diberikan masyarakat kepada laki-laki. Bagi Bhasin maskulinitas mengarahkan laki-laki harus berperilaku, berpakaian dan berpenampilan serta menetapkan sikap dan kualitas apa yang harus dimiliki laki-laki. Mengacu pada definisi ini maka maskulinitas tidak hanya menjadi standar atau rujukan bagi laki-laki dalam mendefinisikan diri mereka akan tetapi juga mengandung norma (masculinity norm) yang harus diikuti laki-laki dengan konsekuensi inklusi dan ekslusi. Dari definisi ini maka maskulinitas seperti dinilai beberapa ilmuwan sosial lebih terkait dengan gender ketimbang sex biologis. Ketika maskulinitas adalah konstruksi sosial maka situasi sosial berperan penting dalam menentukan maskulinitas. Situasi sosial yang beragam dan dinamis membuat maskulinitas tidaklah tunggal akan tetapi plural (beragam).

Michael Kimmel (2004) mengidentifikasi keberagaman maskulinitas dalam empat hal; pertama, maskulinitas berbeda-beda antara satu budaya dengan budaya yang lain. Ketika salah satu budaya bertemu dengan budaya lainnya maka terjadi pencampuran silang budaya akibat adanya kontak budaya, biasanya pencampuran itu menghasilkan budaya dan identitas baru (Suyadi, 2019). Kedua, maskulinitas dalam suatu masyarakat itu tidak statis tapi berkembang dari waktu ke waktu. Ketiga, maskulinitas itu berubah-ubah dalam siklus kehidupan seseorang. Keempat, makna maskulinitas itu bervariasi bahkan dalam suatu masyarakat dalam suatu waktu. Definisi yang diungkapkan Kimmel menegaskan bahwa maskulinitas itu tidaklah universal dan berlaku pada semua laki-laki dalam semua masyarakat sosial sebaliknya beragam bahkan keberagaman maskulinitas yang dianut dan diyakini lakilaki ini lebih beragam dibandingkan dengan perbedaan peran sosial antara laki-laki dan perempuan.

Memperkuat definisi Kimmel, Hayati (2014) berdasarkan kajiannya terhadap pandangan laki-laki tentang maskulinitas di Purworejo membagi maskulinitas dalam tiga kelompok; maskulinitas tradisionalis, pragmatis, dan egalitarian. Maskulinitas tradisionalis adalah menilai laki-laki diciptakan oleh tuhan superior atas perempuan. Maskulinitas pragmatis menilai bahwa laki-laki itu lebih superior atas perempuan akan tetapi memiliki beberapa kekurangan yang dapat dilengkapi oleh perempuan sedangkan maskulinitas egaliter memandang bahwa laki-laki dan perempuan itu memiliki kedudukan yang setara. Berbeda dengan definisi sebelumnya. Raywen Connel (2000) mendefinisikan maskulinitas sebagai konfigurasi praktik-praktik (configuration of practices) dalam relasi gender dalam struktur-struktur yang lebih luas seperti sosial, ekonomi dan politik. Dalam definisi ini Connel memberikan penekanan pada aspek struktur yang mengandaikan hirarkhi dan hubungan kekuasaan. Maskulinitas tidak hanya mengandung unsur relasi kuasa dalam hubungan laki-laki dan perempuan akan tetapi juga antara laki-laki satu dengan laki-laki lainnya. Lebih lanjut Connel membagi maskulinitas dalam tiga kelompok; maskulinitas hegemonik, maskulinitas komplisit, maskulinitas marginal dan maskulinitas sub-ordinat (Hasyim, 2017)

Berbicara rmengenai maskulinitas tentu saja tak bisa lepas dari pembicaraan mengenai gender. Secara umum, gender berbeda dengan jenis kelamin. Jenis kelamin dianggap sebagai konstruksi biologis yang dibawa setiap individu sesuai dengan kodratnya sejak lahir di muka bumi ini. Konstruksi ini pada dasarnya tidak pernah berubah. Sedangkan gender adalah kontruksi sosial dan budaya. Konstruksi ini dibentuk melalui proses panjang dalam kehidupan berbudaya, dari waktu ke waktu. Oleh karena gender bersifat dinamis. Dalam memahami perbedaan gender dan jenis kelamin ini, bisa disimak pemikiran Ivan Hill melalui Budiman. Baginya, gender adalah sebuah distingsi perilaku dalam budaya aernacular. Konsep gender ini membedakan waktu, tempat peralatan, tugas, gerak-gerik, bentuk tuturan dan bermacam persepsi yang dikaitkan pada laki-laki atau perempuan. Perbedaan gender di antara kedua jenis kelamin tersebut akan menjadi lebih lebar ketika masyarakat pun mempertahankan perbedaan, yang sifatnya bukan bawaan sejak lahir. Lebih dari itu, perbedaan itu justru dipertahankan secara kultural (Kurnia, 2004).

Maskulinitas telah lama menjadi ciri bagi seorang laki-laki, maskulinitas dianggap hal yang penting dalam eksistensi di lingkungan. Tak heran ada berbagai cara yang dilakukan untuk membentuk identitas maskulinitas dalam lingkungan tempat berada. Maskulinitas dianggap sebagai identitas yang sangat cocok dan penting dalam diri laki-laki, karena dianggap akan mempengaruhi kehormatan dan martabat laki-laki. Salah satu faktor itulah yang membuat laki-laki memperjuangkan identitas maskulinitas mereka.

Konsep maskulinitas sebagai suatu konstruksi jender tentu saja tidak pernah bebas dari norma-norma sosial yang bisa menghambat terciptanya relasi jender yang setara. Anggapan bahwa konsep maskulinitas itu lebih membebaskan dibandingkan konsep femininitas adalah salah satu alasan utama mengapa diskursus akademik dalam bidang jender masih sangat tidak berimbang. Diskursus jender masih sangat berpusat pada perempuan dan isu-isu yang mengelilinginya (Budiastuti \& Wulan, 2017).

Komunikasi nonverbal berupa informasi atau bisa pula 
diwujudkan melalui emosi yang diungkapkan tanpa menggunakan kata-kata. Komunikasi nonverbal sangat penting, sebab apa yang sering kita lakukan mempunyai makna jauh lebih penting dibanding apa yang kita katakan. Ungkapan klise seperti sebuah gambar sama nilainya dengan seribu kata menunjukkan bahwa alat-alat indra yang kita gunakan untuk menangkapi isyaratisyarat nonverbal sebetulnya berbeda dari kata-kata yang kita gunakan. Komunikasi nonverbal merupakan penciptaan dan pertukaran pesan dengan tidak menggunakan katakata atau dapat juga dikatakan bahwa semua kejadian disekeliling situasi komunikasi yang tidak berhubungan dengan kata-kata yang diucapkan atau dituliskan, dengan komunikasi nonverbal, orang dapat mengekspresikan perasaannya melalui tanda atau simbol-simbol tertentu.

Komunikasi nonverbal ialah penggunaan objek seperti pakaian, simbol-simbol, dan warna. Menurut Mulyana, mengelompokkan komunikasi nonverbal secara umum, terdiri dari yaitu Pertama Penampilan fisik (Cultural artifact), Penampilan fisik seseorang merupakan salah satu hal pertama yang diperhatikan selama komunikasi interpersonal. Bentuk fisik, cara berpakaian dan berhias menunjukkan kepribadian, status sosial, pekerjaan, agama, budaya dan konsep diri. Kedua Warna, Kita sering menggunakan warna untuk menunjukkan suasana emosional, cita rasa, afiliasi politik, dan bahkan mungkin keyakinan. Ada hubungan antara warna yang digunakan seseorang dengan kondisi fisiologis dan psikologisnya, misalnya frekuensi kedipan mata seseorang akan bertambah ketika dihadapkan pada cahaya merah dan berkurang ketika dihadapkan pada cahaya biru. (Umar, 2018)

Fungsi lain dari komunikasi nonverbal adalah mengatur pesan verbal. Pesan-pesan nonverbal berfungsi untuk mengendalikan sebuah interaksi dalam suatu cara yang sesuai dan halus, seperti misalnya anggukan kepala selama percakapan berlangsung.(Kusumawati, 2016)

Tato merupakan objek visual yang dapat dirasakan strukturnya secara penginderaan khususnya secara visual, yang akan menunjukan berbagai perilaku dari makna tato yang kemungkinan pesan tersebut juga terdapat melalui susunan objek gambar secara visual dari berbagai perilaku sifat fisik. Pesan-pesan tertentu dibalik tato bagi pemiliknya seperti ungkapan aktualisasi diri, style, tren, atau bahkan yang mengungkapkan sebuah keanggotaan dari kelompok-kelompok tertentu.

Mengenai seni tato kawan-kawan pemakai tato memberikan pernyataannya terhadap seni tato tubuh, diantara mereka yang memberi pernyataan adalah Helmi Arif Fatoni atau Toni, Irawan atau akrab dipanggil Tukul, Sutong, dan R. Kokoh Nugroho atau Kokoh. Mereka merupakan penggiat karya seni tato, dan pasti memiliki tato yang bermakna ditubuh mereka. Mereka merupakan orang-orang yang telah lama berkecimpung dan para pegiat seni tato. Toni

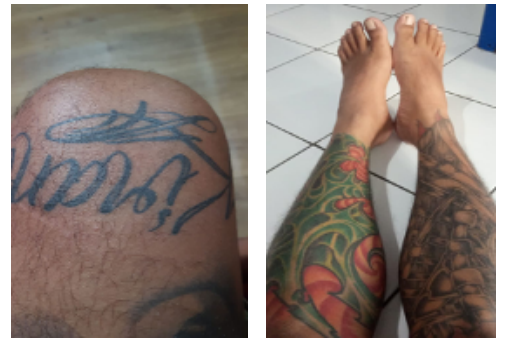

Gambar 1. Tato di bagian dengkul kaki Sutong (sebelah kiri) dan kedua kaki Toni (kanan)

Sumber : Foto Kirman Narasumber Sutong dan Toni

merupakan salah satu anggota komunitas tato "Toekang Tattoo" dan komunitas mural "Rupa Serba Bisa". Sementara Tukul merupakan anggota Indonesian Subculture (ISC) begitupun juga Sutong. Sedangkan Kokoh aktif di komunitas kelas "WOLU" (Workshop Lukisan dan Instalasi) dan Komunitas Rumah Pensil serta Sony dan Ale yang juga sama-sama pegiat seni tato.

Salah satu narasumber bernama Sutong, memiliki tato yang menyimbolkan nama anaknya, simbol ini memiliki kesan yang berarti baginya, sementara tato di kaki Toni memiliki arti jadilah orang baik. Salah satu kebutuhan pokok manusia adalah kebutuhan simbolisasi atau penggunaan lambang-lambang, secara ekstrim dapat dilakukan bahwa manusia adalah satu-satunya makhluk yang menggunakan lambang dan kebutuhan akan lambang tersebut menjadi salah satu pembeda dari makhluk lainnya. Perbedaaan itu menempatkan manusia menjadi lebih unggul atas makhluk lainnya dan perbedaan tersebut merupakan keistimewaan. Dengan kata lain, eksistensi manusia dalam suatu lingungan sosial sangat ditentukan oleh simbolisasi maksud, dan di sisi lain eksistensi dari manusia sangat ditentukan oleh komunikasi sebagai eksistensi diri atau aktualisasi diri (Rasul, 2018). Seperti halnya tato sangat memberi simbol yang bermakna bagi pemakainya, mereka bisa memberi tubuh simbol yang sangat yang menggambarkan sesuatu yang berharga sebagai bentuk kecintaan maupun pengingat diri.

Dimasa sekarang ini tato telah menjadi cerminan bagi keberadaan masyarakat, khususnya kaum muda. Hal ini menunjukan bahwa tato tidak lagi milik kaum preman dan seniman, tapi telah menjadi milik seluruh masyarakat yang menyukai tato. Realitas menunjukan bahwa konsumsi tato didominasi oleh kaum muda, baik di pedesaan maupun di perkotaan. Fenomena ini menunjukan bahwa kaum muda mulai berani secara terang-terangan menunjukan identitas diri mereka. Kaum muda akan sangat bangga dengan sesuatu yang melekat di tubuh mereka, karena dengan itu mereka (kaum muda) merasa mampu menyuarakan ekspresi mereka melalui simbol pada tubuh secara minimalis sekalipun. (Satria, Matheosz \& Mamosey, 2018). tubuh tidak lagi menjadi situs pembuatan budaya tetapi tubuh menjadi tempat budaya tersebut diterapkan. Hal ini misalnya dapat dilihat pada kasus banyaknya lelaki gay yang 


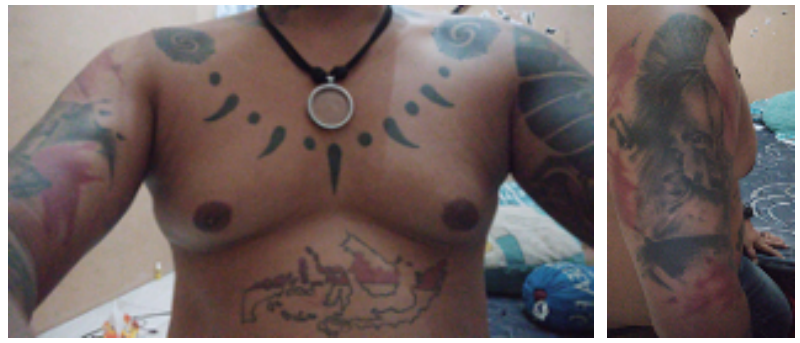

Gambar 2. Tato di tubuh bagian depan Sony (kiri) dan lengan kanan Sony (kanan)

Sumber : Foto Kiriman Narasumber Sony

berhasrat untuk memiliki tubuh atletis dan berotot (Jatnika \& Hermawan, 2018).

Tato bergambar seorang kesatria yang terkesan tegas dan berwibawa dapat menggambarkan pemakainya sebagai seorang yang pemberani seperti tato milik Sony di bagian lengan yang bergambar kesatria Romawi. Selanjutnya masih pada Gambar.2, makna tato tentang kesatuan dalam kebhinekaan terdapat pada lengan Sony dengan menggambarkan peta Negara Indonesia yang diartikan jangan memandang status suku, ras dan agama. Dahulu memang tato digunakan untuk orang yang hendak menjadi dewasa, dengan melalui proses ritual dan sebagainya. Maka kini tato menjadi konsumsi banyak kalangan tanpa memasuki keadaan tertentu dengan tato sebagai simbolnya. Tato bagi kaum muda dianggap atraktif, dinamis, sesuai dengan jiwa muda yang penuh semangat, kreatif meledak-ledak melihat tatanan sosial kultural masyarakat yang mengikat kebebasan dan terasa monoton. Remaja menganggap fashion (tato), aliran musik, hingga bahasa dapat dianggap sebagai usaha memenangkan ruang kultural melawan kebudayaan yang dianut orang tua dan kebudayaan yang berlaku di masyarakat umum. Hal tersebut merupakan bukti penguat tato dari tradisi menjelma dengan budaya tinggi (high culture), menuju budaya pop (pop culture). Dari nilai budaya tato itu sendiri memiliki tujauan dan nilai tersendiri (Satria, Matheosz \& Mamosey, 2018).

Penempatan yang dipilih untuk mempunyai tattoo juga bermacam-macam, sebagian orang memilih untuk mempunyai tattoo yang tidak terlihat dalam artian mereka membuat tattoo dibagian yang tertutup pakaian sehari-hari seperti pada bagian punggung. Namun saat ini mulai banyak mereka yang mempunyai nyali lebih besar dan membuat tattoo yang dapat dilihat kapan saja seperti pada lengan, leher, dan sebagainya. Pada Gambar.3 menunjukkan Tato milik Tukul berada di bagian tangan bawah dekat pergelangan, tato milik Tukul bergambar dua orang wanita cantik. Tukul menjelaskan bahwa wanita menggambarkan keindahan, namun dibalik itu semua terdapat pula keburukan. Perkembangan yang terjadi ini membuat keuntungan bagi pengerajin tato atau tato artis menjadikan tato dalam bidang usaha. Usaha yang di geluti oleh tato artis ialah berbagai macam dari yang menjual jarum tato, vaselin tato, tinta tato, dan berbagai jenis alat tato lainn- ya. Keuntungan yang didapatkan dari hasil usaha ini tidak terbilang kecil, harga tinta yang ukuran kecil sajabias dihargai 15.000, harga jarum 8.0000/buah, untuk jasa penatoan sendiri harga yang diberikan $10.000 / \mathrm{Cm}$. Penatoan dihitung dari besar atau luas gambar tato itu sendiri. Gambar tato akan di ukur sesuai apa yang diberikan contoh, gambar tato naga, itu akan di ukur luasnya panjang dan tinggi gambar tato tersebut. Untuk penatoan juga ada batas minimum harga yang diberikan, luas tato harus lebih dari 10cm (Satria, Matheosz \& Mamosey, 2018).

Pada Gambar.3 memperlihatkan bahwa Ale memiliki tato yang mempunyai nilai keindahan yang tinggi, dengan garis spiral dengan corak menawan, karena terdapat pesan tentang baik hati dan tidak sombong serta pesan untuk selalu terus bekerja kerasSelain mampu mengungkap identitas diri pengguna tato, penggunaan tato juga berkaitan dengan persepsi dari masingmasing penggunanya. Beberapa orang menyebutkan bahwa fenomena tato merupakan sebuah ekspresi perasaan, lambang identitas, serta merupakan karya seni dan keindahan oleh penggunanya. Sebagian lagi menyebutkan bahwa tato merupakan suatu simbol premanisme atau kebrutalan yang menjurus kepada tindak kejahatan. Cara pandang dan penilaian individu atas dirinya yang akan mempengaruhi seseorang dalam bertindak. Sebagai seorang individu yang memiliki tato tentunya mempunyai persepsi tersendiri terhadap tato sehingga berani mengambil keputusan untuk mentato tubuhnya, walaupun ada anggapan negatif dari masyarakat luas yang terbentur oleh nilai-nilai masyarakat Indonesia pada umumnya dan juga larangan dan aturanaturan yang mengikat dalam kehidupan sehari-hari (Rumbiati \& Putra, 2015) . Dalam kesempatan ini kami bertanya pada para pegiat tato atau narasumber kami mengenai persepsi mereka tentang tato.

"Persepsi tentang tato, lebih ke estetika bentuk tubuh, tidak semua orang cocok untuk ditato karena tato harus ngikutin lekuk dan bentuk tubuh, agar enak dilihat dan indah" - Sutong

"Jaman sekarang tato itu sudah jadi seperti fashion jadi sudah melampaui kata "Tato adalah seni" itu kuno, tato itu life style di zaman sekarang”- Toni

\section{"Menurut saya sebagai pelaku tato artis, selain itu sebuah ke indahan, tato itu hidup dan bersinergi"- Tukul \\ "Jangan memberi statement pada orang bertato, bahwa semua orang bertato itu kriminal” - Kokoh}

Selain berkaitan dengan erat dengan dimensi konsep diri, motif tato juga berkaitan dengan beberapa komponen yangmmembangun sebuah konsep diri. Komponen konsep diri yang dimaksud antara lain dirimideal, citra diri dan harga diri. Motif tato yang digunakan oleh masing-masing individu akan menggambarkan citra diri penggunanya. $\mathrm{Ci}$ - 

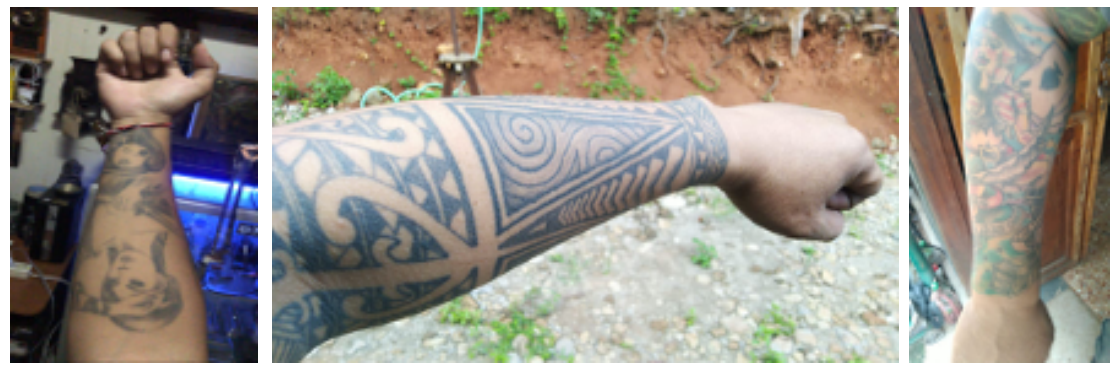

Gambar 3. Tato di tangan Tukul (kiri), di tangan kiri Ale (tengah), dan tangan kanan Ale (kanan) Sumber : Foto Kiriman Narasumber Tukul dan Ale
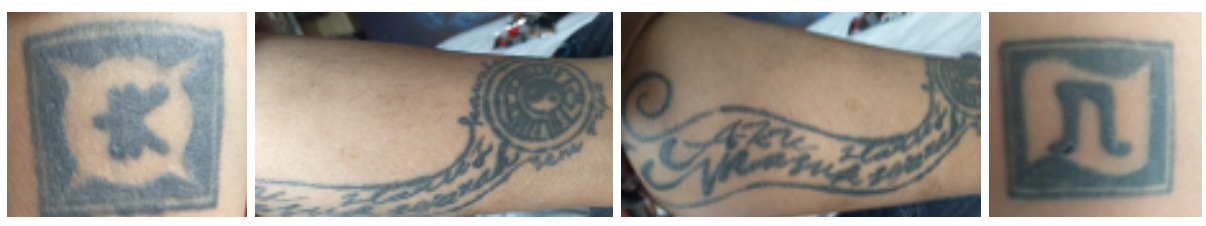

Gambar 4. Kumpulan Motif Tato di Beberapa Bagian Tubuh Kokoh Sumber : Foto Kiriman narasumber Kokoh

tra diri yang dimaksud ialah gambaran diri ideal menurut standar individu tersebut. Selain itu motif tato jugaakan berkaitan dengan bagaimana individu berpikir dan menilai tentang dirinya sendiri. Hal ini pada akhirnya akan mencapai pada suatu standar yang bersifat emosional tentang penilaian diri yang disebut dengan harga diri.

Identitas seseorang juga bisa diungkapkan melalui simbol dalam tato. Tato milik Kokoh pada Gambar.4 berupa simbol-simbol yang berisi tentang filosofi hidupnya. Kokoh mentato tubuh dengan tato yang berisi simbol filosofi hidupnya sebagai pengingat tentang tujuan hidupnya. Ketertarikan seseorang untuk memiliki tato tidak hanya berdasar pada makna yang akan digunakan sebagai desain pada gambar tato, namun juga berdasarkan keindahan sebuah gambar yang akan digunakan sebagai desain pada gambar tatonya. Tato bagi pemiliknya adalah sebuah wujud kreasi, dalam berkreasi tidak hanya ketika pemiliknya termotivasi dan memutuskan untuk membuat tato, namun juga atas desain gambar apa yang akan digunakan sebagai tato. Hal tersebut ditemukan peneliti dari keterangan informan yang menjelaskan bahwa tidak semua tato bagi pemiliknya belum tentu memiliki makna, ketertarikan akan desain gambar tato yang menarik dan mengesampingkan makna tertentu yang terdapat pada gambar tato juga merupakan motivasi bagi pemilik tato untuk menorehkan tato pada tubuhnya. Keinginan dan motivasi seseorang untuk memiliki tato dapat juga dipengaruhi oleh lingkungan pergaulannya, peneliti menemukan adanya tato yang juga digunakan secara simbolis oleh pemiliknya sebagai tanda anggota dari suatu kelompok (Putra, 2015). Motivasi mentato tubuh memilik beberapa macam sesaui kepribadian dari sang pemakai, seperti yang kami tanyakan pada para pegiat toto.

"Menurut saya pribadi motivasi untuk mentato tubuh itu relatif menurut sudut pandang orang masing-masing, karena bagi saya kulit adalah media public yang dibawa kemana saja dan kapanpun, dan sampai mati, itu pun terbentuk dari pembelajaran dari urban art yang penyampaiannya dipresentasikan lewat media publik seperti tembok, papan reklame, dan masih banyak media yang dipakai, akhirnya saya berpikiran kenapa tidak dibawa ke kulit untuk penyampaian makna dan filosofinya dan akhirnya berkembanglah/pindah ke tato sebagai penyampaian arti garis, arti warna, dan arti bentuk" Jawab Sutong jawaban senada di nyatakan oleh Kokoh

"Tato bagi saya adalah sebagai satu simbol yang saya pakai untuk menyadarkan posisi diri saya seperti apa, agar selalu ingat saya pernah berjanji, ada 3 kesepakatan yang saya tanamkan dalam diri saya melalui rajah" Kata Kokoh, sementara, Toni memberik tamnggapan

"Karena saya orang baik, maka saya menato tubuh saya biar masyarakat itu tau kalau tato itu buat orang sebaik saya, saya contoh yang baik" Tutur Toni, seorang pegiat tato dari Ungaran

"Karena tattoo buat aku wujud ekpresi kita, secara tidak langsung tattoo mencerminkan kepribadian kita” Kata Tukul

Seperti halnya sebingkai lukisan atau bentuk seni yang lain, tato juga memiliki aliran gaya visual dan pengguna fanatik. Tribal, black and gray, oldschool, newschool, biomechanical, fantasy dan masih banyak lagi gaya yang lain, tato ini diminati berbagai lapisan dan kelas masyarakat. Hal ini tidak menutup kemungkinan menjadi bagian dari pemikiran posmo (terkini) dalam mewujudkan pesan visual melalui tato. Indonesia merupakan negara kepulauan dengan berbagai macam suku, ras dan agama, tentunya 
bermacam macam pula budaya yang terkandung (Setiawan \& Jayanegara, 2016). Bagi masyarakat yang memiliki budaya tato. Tato pada awalnya dipercaya untuk kebutuhan ritual, untuk itulah biasanya dipilih orang-orang yang punya kecakapan khusus untuk melakukannya. Pendapat lain menyebutkan bahwa, tato adalah salah satu wilayah olah seni dan umurnya sebatas sisa hidup dari penyandangnya (Setiawan \& Jayanegara, 2016). Sebagai produk budaya dan seni yang sudah mengakar lama sekali di nusantara ini, keberadaan tato dalam masyarakat terus ada sampai saat ini dengan berbagai makna dan fungsi yang menempel padanya (Savitri, 2017). Tentang pandangan masyarakat para pegiat seni tato memilik tanggapan yang bermacam-macam berdasar kenyataan yang dialami para pegiat seni tato dilingkungan mereka masing-masing.

"Tanggapannnya yang bermacam-macam, bagi yang tahu tentang tato yang kita biasa dibilang orang merdeka, bagi yang awam yang dibilang preman, karena pergeseran pemikiran sejak orba, ya wajarlah" Ujar Sutong, pemilik studio Urban Tatto di Salatiga, pernyataan tersebut ditimpali oleh Toni.

"Biasa saja, tidak ada yang beda, masyarakat sekarang itu pintar-pintar. Orang -orang tetap baik sama saya karena saya orang baik, Ada bertaubatlah dahulu sebelum bertato karena tato sekarang bukan buat berbuat jahat tapi untuk berbuat kebaikan jadilah individu yang merdeka dan berguna bagi bangsa dan agama” Kata Toni, sementara Tukul menanggapi tentang hal ini

"Tidak semuanya bisa menerima tato itu seni, masih kebanggaan orang menganggap bahwa tato itu negative, (premanisme)" Tambah Tukul

Tato bukan hanya sekedar gambar melainkan memiliki fungsi-fungsi yang bermacam-macam. Seperti, sebagai simbol kejantanan, mempercantik diri, kesuburan dan sebagainya. Tato bagi kalangan tertentu dipandang sebagai sesuatu yang menarik. Di samping itu ada berbagai alasan masyarakat menato tubuhnya, yakni karena iseng-iseng atau coba-coba, diajak teman, trend atau mode, simbol peristiwa tertentu, ekspresi seni perilaku, ekspresi spritualitas atau kepercayaan dan sebagainya (Rahmawati, 2017) Menurut Dwi Marianto dan Syamsul Barry ada dua macam tato. Yang pertama tato permanen. Tato permanen adalah tetap dan tidak berubah-ubah. Artinya bahwa tato itu tidak bisa hilang kecuali dengan cara penyinaran dengan laser, pembedahan maupun pengamplasan. Yang kedua tato temporer. Tato temporer adalah body art yang hasilnya tampak seperti tato, namun tidak menggunakan tusukan-tusukan jarum, dan tidak memasukkan tinta ke dalam kulit. Akan tetapi, tinta hanya ditempelkan di atas permukaan kulit saja dan tidak bisa tahan lama dalam arti bisa hilang dengan sendirinya. Jenis-jenis gambar tato ada dua macam yang pertama jenis flash yaitu tato yang banyak dipilih dan disukai, gambarnya sudah banyak dikenal seperti naga, hati dan jangkar. Jenis kedua adalah custom yaitu tato yang dibuat berdasarkan keinginan atau ide dari orang yang akan ditato. Custom ini dapat dibuat sendiri atau meminta bantuan dari tato artis (Handani \& Azeharie, 2019). Bentuk tato yang dipakai seoarang pegiat tato pun juga beragam tergantung keinginan diri sendiri dan pesan yang ingin disampaikan.

"Kalau saya lebih ke urban tato, karena tato saya tidak bawa tidak perlu orang tahu arti tato saya sendiri, urban lebih menjelaskan arti dari garis, warna, bentuk dan komposisinya pun harus ada artinya” Jelas Sutong, seorang pegiat di komunitas Indonesian Subculture

"Saya lebih suka etnik, tapi dibadan saya selain tato etnik ada juga motif bio organik, bio mekanik, tribal, old skol", Ujar Toni

Sanders (2008) membagi motivasi bertato menjadi lima yaitu simbolisasi dari sebuah hubungan interpersonal, partisipasi dalam sebuah kelompok, simbol identitas diri, presentasi dari ketertarikan utama dan aktivitas, serta pernyataan tentang keindahan estetis. Berdasarkan dari wawancara diatas bahwa ternyata Rosa masuk dalam kategori bahwa tato itu sebagai sebuah simbol identitas diri karena Rosa memiliki tato yang digunakan sebagai pemahamannya atas dirinya sendiri. Sanders (2008) menyatakan bahwa tato digunakan sebagai representasi simbolik dari bagaimana seseorang memahami dirinya sendiri. Menurut Erikson, identitas ego (ego identity) adalah imaji yang dimiliki individu tentang dirinya di beragam peran sosial. Adanya keterhubungan emosional bagaimana tato yang ada pada dirinya dengan keadaan dan kejadian dalam hidupnya (Gumelar \& Mukhroman, 2015). Kadang terjadi adanya pengucilan di bidang sosial bagi para pegiat tato karena adanya persepsi yang salah menganai tato. Namun, hal tersebut tidak mutlak terjadi pada semua pagiat seni tato. Mengenai perbedaan sosial para pegiat tato memiliki tanggapannya.

"Tidak ada perbedaan status sosial...sama saja...orangorang yang membedakan ini malah yang kadang membuat beda status sosial...orang-oramg yg kayak gitu itu biasanya sdm nya maaf ya...agak rendah... mau bergaul atas dasar status sosial" - Toni

"Yang pasti ada yang beranggapan kalau tato itu kriminalisasi atau preman, dampak dari segi jelas ada dua sesi. Tapi tidak apa-apa kan hanya anggapan. Tinggal kita saja menanggapinya dan buktikan bahwa orang bertatto tidak semua yang mereka anggapkan tentunya dari segi negatif", - Tanggap Soni, seorang wirasawasta di Kota Semarang

"Dibiaskan saja, nanti lama kelamaan masyarakat akan mengerti dan terbiasa, tentunya dalam hal-hal baik" jawab Ale, penyuka dan anggota komunitas motor yang memiliki tato 


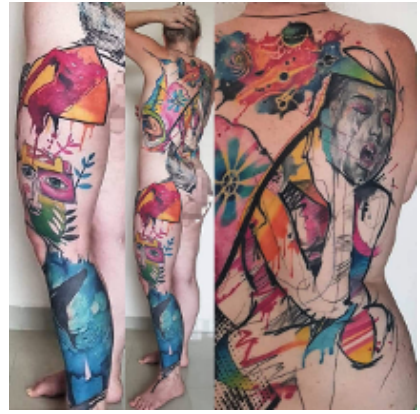

Gambar 5. Sebuah Urban Tatto, yang memiliki makna tentang ibu pertiwi

Sumber : foto kiriman narasumber Sutong

Komunikasi tidak akan pernah bisa lepas dari adanya visual dan verbal. Visual ditandai dengan gambar, verbal ditandai dengan lisan maupun tulisan. Antara visual dengan verbal ini pun memiliki hubungan yang erat. Dalam kehidupan sehari-hari, bahasa verbal (baik lisan maupun tutlisan) selalu memegang peranan yang penting dalam sebuah interaksi serta dipandang sebagai sarana interaksi yang utama, sedangkan bahasa non-verbal dan sarana visual dianggap kurang penting, padahal banyak hasil kerja yang bernilai yang selalu dikaitkan dengan tanda verbal dan nonverbal. Bahasa verbal saja tanpa semua gerak gerak, suara, warna, dan objek material membatasi pemahaman kita terhadap kompleksnya sebuah interaksi dan makna interaksional dapat memberikan pengaruh terbatas pada suatu komunikasi (Kusuma \& Nurhayati, 2019).

Gambar atau tanda di dalam tato merupakan simbol yang mewakili nilai-nilai tertentu. Meskipun simbol yang terlihat bukanlah nilai itu sendiri, namun keberadaan simbol tersebut dibutuhkan untuk kepentingan penghayatan akan nilai-nilai yang diwakilinya dan merepresentasikan simbol tersebut secara nyata di atas kulit tubuh akan lebih memperkuat penghayatan akan nilai-nilai yang diwakilinya. Tato merupakan tanda atau penanda, sebuah karya seni hasil peradaban yang sekaligus juga merupakan sebuah media dalam masyarakat untuk saling mengenal, berkomunikasi, dan menunjukkan eksistensinya (Sholekhuddin, 2016)

"Sebenarnya tato itu sudah ada sebelum agama, di mesir, peru, himalaya, thailand, dimana-mana ada sejarah tentang tato, terutama di Indonesia tidak hanya di dayak yang tato di pakai sebagai identitas/kasta, dijawa dan dibali kuno juga ada tato tradisionalnya, yang dipakai setiap hari oleh penduduk jawa dan digunakan kehidupan sehari-hari. Contohnya dipakai anti luka/kebal/mudah percaya, menaklukan binatang. Makanya belanda susah menaklukkan kita di jawa karena kita kebal peluru, makanya kita bisa diadu domba dan lontar tato semuanya dibawa ke belanda dan sekarang dipelajari, lontar tato jawa kuno itu sebenarnya menggunakan bahasa roh di alam, dan prosesnya meditasi, ada bahasa rah, jah mah, kah, dan masih banyak lagi" Ungkap Sutong

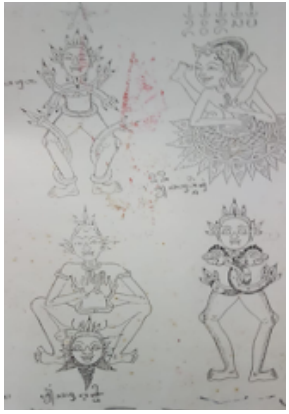

Gambar 6. Tato Jawa dan Tato Bali Kuno Sumber : Foto Koleksi Narasumber Sutong

Tato memiliki nilai yang menunujukkan maskulinitas seseorang. Perbedaan maskulin dan feminin pun menggiring anggapan umum bahwa karakteristik maskulin lekat dengan laki-laki, dan karakter ini dikaitkan dengan tiga sifat khusus yaitu kuat, keras, beraroma keringat. Secara sederhana laki-laki dilabeli sifat macho. Sementara itu, karakteristik perempuan diidentikkan dengan sifat yang lemah, lembut, dan beraroma wangi yang sekaligus dikaitkan dengan sifat seorang putri (Linggosiswojo, 2016). Tentang image tato yang baik, kami menanyakan tentang bagaimana cara mensosialisasikan atau mewujudkan keberadaan tato agar mendapatkan image bersih, sehat, dan aman berdasar konsep yang jelas serta dapat diterima oleh pemerintah ataupun masyarakat lainnya pada para pegiat tato

"Mensosialisaikan dengan berperilaku laku yang baik, sudah banyak kok yang pintar dan tahu tato jadi tidak selalu buruk imagenya, pemerintah juga sudah menerima apa itu tato karena sejak zaman orba runtuh suply tato yang dari luar negeri pun baru bisa masuk ke indonesia, dan sudah ada SOPnya dari dinas kesehatan, hanya tato belum bisa masuk ke ranah agama, kembali ke sudut pandang masing-masing" - Sutong

"Banyak sebenarnya yang masyarakat awam mungkin belum mengetahui tato itu sebenarnya seperti apa dan bagaimana cara membikinnya, dengan kita mengedukasi terutama akan sejarah tato, kesehatan tato, arti sebuah tato dan masih banyak lagi, dan negara kita kan punya tradisi tato turun temurun yang masih di pertahankan hingga saat ini" - Tukul, seorang pegiat seni tato dari Banyumanik, Kota Semarang

Meski maskulinitas dan femininitas adalah konsep nilai yang kontradiktif, tapi keduanya dapat dipertukarkan. Artinya, femininitas tidak mesti hanya dimiliki perempuan dan maskulinitas tidak hanya dimiliki laki-laki. Sebab pada praktiknya, laki-laki mengandalkan sikap feminin Misal, dalam pekerjaan mereka tidak serta merta hanya mengandalkan keberanian, tapi juga harus berkomunikasi secara lembut, sopan, dan tidak semena-mena. Kemudian pada pihak perempuan, masyarakat memandang mereka sebagai sosok lemah lembut, pasif, dan pemalu. Stereo- 
tipe ini tidak selamanya berlaku secara murni dalam masyarakat. Dalam praktiknya, perempuan juga mengandalkan kekuatan saat bekerja. Mereka juga menggunakan ketegasan serta keberanian saat memutuskan suatu hal dalam menghadapi situasi tertentu (Tanjung, 2012). Maskulinitas yang didapatkan pun berbeda dari setiap pribadi seseorang.

"Yang aku pikir dari yang aku tangkap dari masyarakat itu lebih mengarah ke artistic dan keren, lebih gagah menurutku tidak juga, kalau sejarah iya" - Kokoh, pegiat tato yang memiliki studio tato di Jl. Anggrek I no. 18.

Simbol mengacu pendapat adalah objek atau peristiwa apapun yang menunjuk pada sesuatu. (Heriwati , 2010). Gambar desain yang dibuat setiap pemakai tato bersifat berbagai ragam karena tato adalah suatu yang simbolik, sebab desain yang tercipta dengan latar belakang makna daro tradisional hingga nuansa sekular. Dalam hal ini ada beberapa jenis gambar yang sering dipakai untuk tato dan makna dalam tato tersebut. Seorang laki-laki pasti ingin terlihat jantan dan perkasa ketika di tato pada tubuhnya. Banyak orang menggunakan tato untuk mendapatkan berbagai jenis makna, arti dan maksud tato. Nilai tato saat ini sangat berbeda dari apa yang sekarang. Ini adalah beberapa sudut pandang nilai-nilai tato dari hasil studi lapangan. Tato untuk keberanian, Tato juga terukir sebagai simbolisme keberanian. Tentara yang digunakan untuk mendapatkan tato seperti pedang dan lengkungan terukir di tangan mereka. Ada yang diberi lambang dalam bentuk tato sebagai bentuk untuk keberanian. Orang yang memakai ini lebih cenderung untuk memamerkan tato yang jantan bahwa dirinya berani untuk menato tubuhnya sedemikian rupa. (Satria, Matheosz \& Mamosey, 2018).

Tato merupakan seni yang indah juga penyampai pesan yang sangat bermakna. Tato dipakai selain sebagai penghias tubuh, juga sebagai ekpresi identitas seseorang. Salah satu identitas yang dapat dibawakan oleh tato adalah identitas maskulinitas. Identitas ini sangat erat dengan identitas sebagai seorang laki-laki, tapi identitas ini tidak hanya berlaku bagi kaum laki-laki saja.

Identitas maskulinitas yang dibawa tato bukan sekedar membedakan jenis kelamin antara laki-laki, tapi lebih dari itu identitas maskulinitas yang dibawakan dari sebuah karya tato adalah bagaimana keberanian seseorang dalam menyampaian ekspresi mereka kepada publik. Simbol-simbol yang ada dalam tato memiliki makna yang mendalam bagi pemakainya. Tato sangat berperan dalam kehidupan para pemakainya, seperti menambah kepercayaan seseorang, bukti kecintaan pada keluarga dan bukti kecintaan pada alam sekitar merupakan pesan yang harus disampaikan pada publik sebagai identitas mereka. Pada fenomena sekarang tidak semua tato digunakan untuk menunjukkan identitas maskulinitas seseorang. Tetapi, kesan maskulinitas seseorang memang sudah melekat pada sebuah seni tato yang pastilah mempengaruhi pada pemakainya. Maka tak heran tato menjadi sebuah identitas maskulinitas seseorang

\section{SIMPULAN}

Identitas sendiri merupakan bentuk karakter yang melekat dan penanada bagi keberadaan individu, salah satunya maskulinitas yang erat dengan laki-laki. Kamla Bashin (2004) secara sederhana mendefinisikan maskulinitas sebagai definisi sosial yang diberikan masyarakat kepada laki-laki. Konsep maskulinitas sebagai suatu konstruksi jender tentu saja tidak pernah bebas dari norma-norma sosial yang bisa menghambat terciptanya relasi jender yang setara. Anggapan bahwa konsep maskulinitas itu lebih membebaskan dibandingkan konsep femininitas adalah salah satu alasan utama mengapa diskursus akademik dalam bidang jender masih sangat tidak berimbang. Diskursus jender masih sangat berpusat pada perempuan dan isu-isu yang mengelilinginya. Maskulinitas telah lama menjadi ciri bagi seorang laki-laki, maskulinitas dianggap hal yang penting dalam eksistensi di lingkungan. Tak heran ada berbagai cara yang dilakukan untuk membentuk identitas maskulinitas dalam lingkungan tempat berada.

Komunikasi nonverbal merupakan penciptaan dan pertukaran pesan dengan tidak menggunakan katakata atau dapat juga dikatakan bahwa semua kejadian disekeliling situasi komunikasi yang tidak berhubungan dengan kata-kata yang diucapkan atau dituliskan, dengan komunikasi nonverbal, orang dapat mengekspresikan perasaannya melalui tanda atau simbol-simbol tertentu. Komunikasi nonverbal ialah penggunaan objek seperti pakaian, simbol-simbol, dan warna Gambar atau tanda di dalam tato merupakan simbol yang mewakili nilainilai tertentu. Meskipun simbol yang terlihat bukanlah nilai itu sendiri, namun keberadaan simbol tersebut dibutuhkan untuk kepentingan penghayatan akan nilai-nilai yang diwakilinya dan merepresentasikan simbol tersebut secara nyata di atas kulit tubuh akan lebih memperkuat penghayatan akan nilai-nilai yang diwakilinya. Tato merupakan tanda atau penanda, sebuah karya seni hasil peradaban yang sekaligus juga merupakan sebuah media dalam masyarakat untuk saling mengenal, berkomunikasi, dan menunjukkan eksistensinya Tato memiliki nilai yang menunujukkan maskulinitas seseorang. Perbedaan maskulin dan feminin pun menggiring anggapan umum bahwa karakteristik maskulin lekat dengan laki-laki, dan karakter ini dikaitkan dengan tiga sifat khusus yaitu kuat, keras, beraroma keringat. Secara sederhana laki-laki dilabeli sifat macho. Sementara itu, karakteristik perempuan diidentikkan dengan sifat yang lemah, lembut, dan beraroma wangi yang sekaligus dikaitkan dengan sifat seorang putri. 


\section{DAFTAR RUJUKAN}

Altez, Fleurdeliz R, Albela. (2011). The Body and Transcendence in Emmanuel Levinas' Phenomenological Ethics. Kritike, 5(1), 36-50.

Budiastuti, A., \& Wulan, N. (2017). Konstruksi Maskulinitas Ideal Melalui Konsumsi Budaya Populer oleh Remaja Perkotaan. Mozaik Humaniora, 14(1), 8. https://e-journal. unair.ac.id/MOZAIK/article/view/3845.

Dalensang, R. F. (2019). SENI MELUKIS TUBUH “ Merekonstruksi Pemahaman dan Sikap Gereja T erhadap Fenomena Tato yang Berkembang di Kalangan Muda . Jurnal UNIERA 8(1), 47-57. https://journal.uniera.ac.id/ jview/152.

Gumelar, R. G., \& Mukhroman, I. (2015). Tato: Representatif Gender Dalam Perspektif Feminisme. Jurnal Kajian Komunikasi, 3(1), 71-80. https://jurnal.unpad.ac.id/jkk/ article/view/7396.

Handani, I., \& Azeharie, S. (2019). Analisis Semiotika Tato Tradisional Suku Mentawai. Koneksi, 3(1), 49. https://www.journal.untar.ac.id/index.php/koneksi/article/ view/6144.

Hasyim, Nur. (2017). Kajian Maskulinitas dan Masa Depan Kajian Gender dan Pembangunan di Indonesia. Jurnal Sosiologi Walisongo, 1(1). 68. http://journal.walisongo. ac.id/index.php/JSW/article/view/1938.

Heriwati, Sri Hesti. (2010). SEMIOTIKA DALAM PERIKLANAN. Pendhapa, 1(1). 1-15. https://jurnal.isiska.ac.id/index.php/pendhapa/article/view/1675.

I Nyoman Anom Fajaraditya Setiawan, I. N. J. (2016). Kajian Motivasi Tato Rangda pada Orang Bali. An 1mage Jurnal Studi Kultural, 1(1), 28-34. https://journals.an1 image. net/index.php/ajsk/article/view/46.

Jatnika, A. W., \& Hermawan, F. F. (2018). Menjadi Lelaki Sejati : Maskulinitas Dalam Komik Daring Webtoon Indonesia. MUDRA : Jurnal Seni Budaya 33(1), 62. https:// jurnal.isi-dps.ac.id/index.php/mudra/article/view/158/188

Kurnia, N. (2004). Representasi Maskulinitas dalam Iklan. Jurnal Ilmu Sosial Dan Ilmu Politik, 8(1), 17-36. https:// https://jurnal.ugm.ac.id/jsp/article/view/11056.

Kusuma, P. K. N., \& Nurhayati, I. K. (2019). Analisis Semiotika Roland Barthes Pada Ritual Otonan Di Bali. Jurnal Manajemen Komunikasi, 1(2), 195. https://jurnal. unpad.ac.id/manajemen-komunikasi/aticle/view/10519.

Kusumawati, Tri Indah. (2016). KOMUNIKASI VERBAL DAN NONVERBAL. Al-Irsyad: Jurnal Pendidikan dan Konseling, 6(2). 98. http://jurnal.uinsu.ac.id/index. php/al-irsyad/article/view/6618.

Linggosiswojo, S. G. (2016). Representasi Maskulinitas dalam Iklan Televisi Umild "Kode Cowo." Jurnal E-Komunikasi, 4(2). http://publication.petra.ac.id/index.php/ ilmu-komunikasi/article/view/4847/4456

Putra, Ferdian Ardani. (2015). STUDI FENOMENOLOGI TATO SEBAGAI IDENTITAS DIRI PADA PEMAKAI TATO DI JEMBER Paradigma Madani, 2(2), 105-126. https://ejurnal.uij.ac.id/index.php/PAR/article/view/44.

Rahmawati, Isnaini. (2017). Semiotik Teks Roland Barthes Dalam Kehidupan Kontemporer Umat Beragama Mengenai Fenomena Padu Padan Kebaya Jurnal Kebudayaan Dan Sastra Islam. 17(2). 887-894.https://jurnal. radenfatah.ac.id/index.php/tamaddun/article/view/2532.

Rediasa, I. N. \& Sutrisno, B. (2015). PERTUNJUKAN BODY PAINTING DI BALI SEBAGAI OBJEK PARIWISATA. Jurnal Kajian Seni, 02(01), 52-67. https://jurnal.ugm.ac.id/jks/article/view/11649/8654.

Rumbiati, A. R. \& Putra, Y. Y. (2015). Konsep diri pada masyarakat mentawai yang memakai tato. Jurnal RAP UNP. 06(2). 114-125. http://ejournal.unp.ac.id/index.php/ psikologi/article/view/6614.

Satria,Bara., Mathoesz, J. N., \& Mamosey, W.E. (2018). NILAI BUDAYA TATOO PADA KALANGAN ANAK MUDA KOTA MANADO. Jurnal Holistik, (22), 1-17. https://ejournal.unsrat.ac.id/index.php/holistik/article/ view/22566.

Savitri, I. D. (2018). Budaya dan seni tato pada perempuan sebuah interpretasi ketimuran. Jurnal Studi Budaya Nusantara 1(2), 91. https://jsbn.ub.ac.id/index.php/sbn/ article/view/25.

Setyawati, L. (2010). Keberagaman dan Eksklusi Sosial: Simbol Identitas dalam Ruang Publik. Jurnal Masyarakat Dan Budaya, 117-136. http://jmb.lipi.go.id/index.php/ jmb/article/154.

Sobon, Kosmas. (2018). KONSEP TANGGUNG JAWAB DALAM FILSAFAT EMMANUEL LEVINAS. Jurnal Filsafat 28(1), 60-61. https://jurnal.ugm.ac.id/wisdom/article/view/31281

Sholekhuddin, T. (2016). KONTESTASI SIMBOLIK SENIMAN TATO PADA ARENA SURABAYA TATTOO ARTIST COMMUNITY. Terob 6(2), 614-632. https://ejournal.stkw-surabaya.ac.id/index.php/jtr/article/view/45.

Suyadi. (2019). Hibriditas budaya dalam ketoprak dor. Jurnal Masyrakat Dan Budaya, 21(2), 191-202. http:// 
jmb.lipi.go.id/index.php/jmb/article/817.

Tanjung,Sumekar. 2012. Pemaknaan Maskulinitas pada Majalah Cosmopolitan Indonesia. Jurnal Komunikasi. 6(2). https://journal.uii.ac.id/jurnal-komunikasi/article/ view/6383.

Umar, R. H . (2018). Makna Tato di Kalangan Pengguna Tato di Kota Palu. Konesik, 5(1), 3 https://jurnal.untad. ac.id/jurnal/index.php/Kinesik/article/view/10173/pdf. . 